\title{
Efek Profilaksis Norepinefrin Kontinu pada Anestesi Spinal Pasien Seksio Sesarea terhadap Hemodinamik dan Kontraksi Uterus
}

\author{
${ }^{1}$ Riki Punisada, ${ }^{2}$ Radian Ahmad Halimi, ${ }^{2}$ Dewi Yulianti Bisri \\ ${ }^{1}$ Rumah Sakit Umum Daerah Dr. M. Yunus Bengkulu, ${ }^{2}$ Departemen Anestesiologi dan Terapi Intensif, Fakultas \\ Kedokteran Universitas Padjadjaran-RSUP Dr. Hasan Sadikin Bandung
}

\begin{abstract}
Abstrak
Latar Belakang: Hipotensi merupakan suatu komplikasi setelah anestesi spinal dan dapat mempengaruhi kontraksi uterus pada operasi seksio sesarea (SC). Profilaksis norepinefrin kontinu dapat diberikan untuk mengurangi kejadian hipotensi pascaspinal pada pasien yang menjalani SC. Norepinefrin menjadi kandidat yang baik sebagai alternatif pencegahan hipotensi.

Tujuan: Penelitian ini untuk mengetahui efek profilaksis norepinefrin kontinu terhadap pencegahan hipotensi akibat anestesi spinal dan pengaruhnya terhadap kontraksi uterus.

Subjek dan Metode: Penelitian ini dilakukan di RSUP Dr. Hasan Sadikin Bandung. Metode penelitian uji acak klinis tersamar ganda pada 36 pasien hamil cukup bulan berusia 18-35 tahun, status fisik ASA II ,menjalani SC dengan anestesi spinal. Subjek penelitian dibagi menjadi 2 kelompok yaitu kelompok kontrol $(\mathrm{NaCl} 0,9 \%)$ dan kelompok norepinefrin (norepinefrin intravena setelah tindakan anestesi spinal dengan injeksi sebanyak $5 \mu \mathrm{g}$, kemudian di titrasi sebanyak $0,05 \mu \mathrm{g} / \mathrm{kgbb} / \mathrm{menit}$ ). Data dianalisis dengan uji t test, uji Mann Whitney dan uji kolmogorov-smirnov, nilai $\mathrm{p}<0,05$ dianggap bermakna.

Hasil: Penurunan tekanan darah pada kelompok kontrol (61.1\%) lebih tinggi dari kelompok norepinefrin (11.1\%) dengan perbedaan signifikan $(\mathrm{p}<0,05)$. Kontraksi uterus yang adekuat lebih cepat tercapai pada kelompok norepinefrin dibandingkan kelompok kontrol $(\mathrm{p}<0,05)$.

Simpulan: Profilaksis noreprinefrin kontinu dapat mencegah dan menurunkan angka kejadian hipotensi anestesi spinal dan meningkatkan kontraktilitas uterus pada pasien yang menjalani operasi SC.
\end{abstract}

Kata kunci: Anestesi spinal, hipotensi, norepinefrin, seksio sesarea

\section{Effects of Continuous Norepinephrine Prophylaxis in Spinal Anesthesia Cesarean Section Patients on Hemodynamics and Uterine Contractions}

Abstract

Background: Hypotension is a complication of spinal anesthesia and may affect uterine contraction in cesarean sections (CS). Continuous norepinephrine prophylaxis may be administered to reduce the incidence of post-spinal hypotension in patients undergoing CS. Norepinephrine is an greatest alternative candidate for prevention of postspinal hypotension and has the potential to increase uterine contractions.

Objective: The objective is to known prophylaxis effect of continuous of norepinephrine administration in preventing post-spinal hypotension and its effects on uterine contractions.

Subject and Methods: This study was in Dr. Hasan Sadikin General Hospital Bandung. This was a clinical double blinded study on 36 term pregnant patients aged 18-35 years old with physical ASA status II who underwent $\mathrm{CS}$ on spinal anesthesia. The subjects were randomly divided into 2 groups, a control group $(\mathrm{NaCl} 0,9 \%)$ and a norepinephrine group (intravenous prophylactic $5 \mu \mathrm{g}$ norepinephrine after spinal anesthesia by bolus injection, then titrated $0,05 \mu \mathrm{g} / \mathrm{kgBW} /$ minute). Data was analyzed using the t test, the Mann-Whitney test, and the KolmogorovSmirnov test, a $\mathrm{p}$ value of $<0.05$ was considered significant.

Result: Reduction of blood pressure in the control group $(61.1 \%)$ was higher than in the norepinephrine group $(11.1 \%)$ with a significant difference $(\mathrm{p}<0.05)$. Adequate uterine contraction was sooner achieved in the norepinephrine group compared to the control group $(\mathrm{p}<0.05)$.

Conclusion: Continuous of norepinephrine prophylaxis may prevent and reduce the incidence of hypotension due to spinal anesthesia and increases uterine contractility in patients undergoing CS.

Key words: Cesarean section, hypotension, norepinephrine, spinal anesthesia

This article is licensed under a

Creative Commons Attribution-NonCommercial-ShareAlike 4.0 International License.

CRiki Punisada, Radian Ahmad Halimi, Dewi Yulianti Bisri

(2021) under the CC-BY-NC-SA license

JAOI 2021;4(2): 79-92 


\section{Pendahuluan}

Pemilihan anestesi saat persalinan seksio sesarea harus mempertimbangkan keselamatan ibu dan janin. Anestesi regional merupakan pilihan yang paling banyak digunakan dengan angka mencapai 95\% di Amerika Serikat pada seksio sesarea terencana. ${ }^{1}$ Anestesi spinal merupakan jenis anestesi regional yang sering menjadi pilihan utama karena kemudahan tekniknya serta efektivitasnya dalam memberikan blokade sensorik dan motorik. ${ }^{1}$ Hipotensi setelah anestesi spinal terjadi dikarenakan blokade saraf simpatik yang menyebabkan vasodilatasi perifer dan pengumpulan darah vena, akibatnya venous return dan cardiac output menjadi berkurang sehingga menyebabkan hipotensi. Hal ini menjadi lebih buruk pada pasien hamil di mana terjadi perubahan fisiologis serta resistensi terhadap vasoperesor yang menjadi resiko utama sehingga menyebabkan lebih tingginya angka kejadian hipotensi pada ibu hamil. ${ }^{2}$ Usaha untuk mencegah kejadian komplikasi hipotensi pascaspinal adalah manipulasi posisi pasien dan pemberian preloading cairan. Teknik manipulasi posisi umumnya bertujuan untuk meningkatkan aliran balik vena sehingga terjadi peningkatan curah jantung. ${ }^{1,3}$ Pemberian preloading cairan, baik koloid maupun kristaloid, diharapkan terjadi ekspansi volume intravaskular yang meskipun tidak menghilangkan namun dapat meminimalisir resiko terjadinya hipotensi. ${ }^{1}$

Penggunaan vasopresor seringkali digunakan bahkan telah menjadi prosedur rutin untuk mencegah kejadian hipotensi pascaspinal. Norepinefrin merupakan jenis vasopresor yang belum lama ini diperkenalkan penggunaannya untuk anestesi pasien obstetri. Aktivitas obat ini bersifat agonis $\alpha$-adrenergik dengan tambahan agonis $\beta$-adrenergik lemah. Karakteristik ini membuat norepinefrin hanya menyebabkan depresi kerja jantung minimal, sehingga menjadikannya kandidat yang baik untuk alternatif bagi fenilefrin. Selain itu penggunaan norepinefrin juga tidak menyebabkan takikardi dan tidak mempengaruhi $\mathrm{pH}$ janin, yang sering ditemukan pada pemberian efedrin. Namun pemberian norepinefrin sebagai tatalaksana hipotensi setelah anestesi spinal pada ibu hamil masih menjadi bahan pertimbangan medik., Dengan latar belakang inilah maka penulis ingin mengetahui bagaimana efek dari pemberian profilaksis norepinefrin kontinu terhadap tekanan darah dalam pencegahan hipotensi akibat anestesi spinal, dan pengaruhnya terhadap kontraksi uterus pada operasi seksio sesarea dengan kelompok kontrol.

\section{Subjek dan Metode Penelitian}

Subjek penelitian adalah pasien yang akan menjalani seksio sesarea dengan anestesi regional spinal yang dirawat di RSUP dr. Hasan Sadikin Bandung dan telah mendapatkan persetujuan secara tertulis dari pasien atau wali setelah diberikan penjelasan (informed consent) untuk ikut dalam penelitian. Pengambilan sampel dilakukan secara consecutive sampling diambil dari subjek penelitian yang memenuhi kriteria inklusi dan eksklusi. Dengan menggunakan rumus penentuan besar sampel untuk penelitian analitis kategorik numerik tidak berpasangan, jumlah sampel minimal untuk masing-masing kelompok adalah 18 orang. Maka jumlah total sampel minimal adalah sebesar 36 orang pasien. Kriteria inklusi adalah pasien hamil berusia dewasa 18-35 tahun, pasien hamil cukup bulan, pasien dengan kehamilan tunggal, Body Mass Index (BMI) 25-30, status fisik pasien ASA II (American Society of Anesthesiologist), tinggi badan $\geq 150$ atau $\leq 180 \mathrm{~cm}$. Kriteria eksklusi adalah pasien dengan kelainan jantung, pasien yang menolak tindakan anestesi spinal, pasien gemeli, polihidroamnion, pasien dengan gangguan hipertensi dalam kehamilan, pasien yang mengalami pendarahan peripartum. Kriteria pengeluaran adalah terjadi perdarahan yang lebih dari $750 \mathrm{ml}$ dan pasien yang mengalami gagal spinal anestesi.

Penelitian ini adalah penelitian Randomized Controlled Trial (RCT) dengan metode double blind. Desain penelitian adalah untuk mengetahui perbandingan efek pemberian profilaksis norepinefrin kontinu terhadap kelompok kontrol pada penilaian tekanan darah dalam pencegahan hipotensi akibat anestesi spinal pada operasi 
seksio sesarea dan pengaruhnya terhadap kontraksi uterus. Subjek dibagi ke dalam dua kelompok, yaitu kelompok norepinefrin yang diberikan preloading cairan koloid dengan profilaksis norepinefrin dan kelompok kontrol yang diberikan preloading cairan koloid dengan pemberian $\mathrm{NaCl} 0.9 \%$.

Kedua kelompok penelitian masing-masing mendapat preloading cairan koloid, yaitu cairan koloid sebanyak $7 \mathrm{ml} / \mathrm{kgbb}$ yang diberikan melalui jalur intravena $18 \mathrm{G}$ sebelum tindakan anestesi spinal selama 20 menit dengan pompa infus. Sedangkan pemberian profilaksis norepinefrin tidak diketahui oleh subjek maupun pelaksana prosedur. Kelompok kontrol akan mendapatkan sebuah amplop berisi sebuah spuit berisi cairan normal salin yang akan diberikan secara bolus intravena dan sebuah spuit berisi cairan normal salin yang akan diberikan melalui infus. Sedangkan kelompok norepinefrin akan mendapatkan amplop berisi sebuah spuit berisi cairan norepinefrin $5 \mu \mathrm{g}$ yang akan diberikan secara bolus intravena yang dilanjutkan dengan rumatan norepinefrin dengan dosis titrasi infus yaitu $0,05 \mu \mathrm{g} / \mathrm{kg} /$ menit setelah dilakukan anestesi spinal. Kedua kelompok akan dilakukan penilaian tekanan darah dan kontraksi uterus dengan menggunakan Linear Analog Scale (LAS). Penilaian ini dilakukan dengan cara palpasi oleh dokter spesialis obstetri dan ginekologi pada uterus pasien selama operasi seksio sesarea berlangsung dengan skala 0 hingga 10. LAS 0 menunjukkan tidak adanya kontraksi uterus sama sekali, sementara LAS 10 berarti uterus berkontrasi penuh. LAS $\leq 6$ menunjukkan kontraksi uterus yang kurang optimal sehingga membutuhkan tambahan obat-obatan uterotonik. Data yang didapatkan akan diolah menggunakan SPSS versi 24.0 for Windows dan disajikan dalam tabel dan grafik.

\section{Hasil}

Penelitian dilakukan pada 36 pasien yang akan menjalani seksio sesarea dengan anestesi regional spinal yang dirawat di RSUP dr. Hasan Sadikin Bandung dan telah memenuhi kriteria inklusi penelitian serta tidak memenuhi kriteria eksklusi dan telah setuju untuk mengikuti penelitian dengan menandatangani lembar persetujuan setelah dilakukan informed consent. Subjek dibagi menjadi dua kelompok, terdiri atas 18 subjek kelompok kontrol dan 18 subjek kelompok norepinefrin. Karakteristik subjek penelitian dapat dilihat pada Tabel 1 .

Perbandingan angka kejadian hipotensi tergambar pada Tabel 4.2. Dari 18 subjek pada kelompok kontrol, 11 subjek mengalami hipotensi $(61,1 \%)$ sedangkan dari 18 subjek kelompok norepinefrin, hanya dua subjek yang mengalami hipotensi $(11,1 \%)$. Angka kejadian hipotensi menunjukkan perbedaan secara statistik bermakna yang ditunjukkan oleh nilai $p<0,05$. Perbandingan penurunan Tekanan Darah Sistolik (TDS) antara kelompok kontrol dan kelompok norepinefrin sejak sebelum induksi, menit awal sampai dengan menit ke-60 tergambar pada Tabel 4.4 dan grafik 4.1. Perbedaan TDS antara kelompok kontrol dan norepinefrin menunjukkan perbedaan secara statistik bermakna pada setiap waktu pengukuran yang ditunjukkan oleh nilai $\mathrm{p}<0,05$. Hasil uji statistika pada kelompok penelitian diatas diperoleh informasi nilai $\mathrm{P}$ pada variabel penurunan tekanan darah sistolik menit ke-4, ke5, ke-6, ke-7, ke-8, ke-14, ke-18, ke-20, ke-25, ke-30, ke-35, ke-40, ke-45, ke-50, ke-55, dan ke-60 lebih kecil dari 0.05 (nilai $\mathrm{p}<0.05$ ) yang berarti signifikan atau bermakna secara statistik, dengan demikian dapat dijelaskan bahwa terdapat perbedaan rerata yang signifikan secara statistik antara variabel tersebut pada kelompok kontrol dan norepinefrin. Sedangkan nilai P pada variabel penurunan tekanan darah sistolik menit ke-0, ke-1, ke-2, ke-3, ke-10, ke-12, dan ke-16 lebih besar dari 0.05 (nilai $p>0.05$ ) yang berarti tidak signifikan atau tidak bermakna secara statistik. Dengan demikian dapat dijelaskan bahwa terdapat mayoritas perbedaan rerata yang signifikan secara statistik pada TDS antara kelompok kontrol dan norepinefrin

Perbandingan penurunan Tekanan Darah Diastolik (TDD) antara kelompok kontrol dan kelompok norepinefrin sejak sebelum induksi, menit awal sampai dengan operasi selesai tergambar pada Tabel 4.5 dan Gambar 4.2. Hasil uji statistika 
Tabel 1. Perbandingan Karakteristik Subjek Penelitian pada Kedua Kelompok

\begin{tabular}{|c|c|c|c|}
\hline \multirow[t]{2}{*}{ Variabel } & \multicolumn{2}{|l|}{ Kelompok } & \multirow[t]{2}{*}{ Nilai $P$} \\
\hline & $\begin{array}{l}\text { Kontrol } \\
\mathrm{N}=18\end{array}$ & $\begin{array}{l}\text { Norepinefrin } \\
\mathrm{N}=18\end{array}$ & \\
\hline Usia & & & 0.501 \\
\hline Mean \pm Std & $28.28 \pm 4.084$ & $28.78 \pm 4.760$ & \\
\hline Median & 28.50 & 30.50 & \\
\hline Range (min-max) & $19.00-33.00$ & $20.00-34.00$ & \\
\hline Tinggi Badan (cm) & & & 0.254 \\
\hline Mean \pm Std & $159.67 \pm 4.325$ & $158.17 \pm 3.365$ & \\
\hline Median & 159.00 & 159.00 & \\
\hline Range (min-max) & $152.00-168.00$ & $150.00-165.00$ & \\
\hline Berat Badan (kg) & & & 0.070 \\
\hline Mean $\pm S t d$ & $68.89 \pm 3.969$ & $66.11 \pm 4.885$ & \\
\hline Median & 69.00 & 65.00 & \\
\hline Range (min-max & $63.00-75.00$ & $60.00-75.00$ & \\
\hline BMI & & & 0.257 \\
\hline Mean \pm Std & $27.05 \pm 1.669$ & $26.42 \pm 1.610$ & \\
\hline Median & 26.69 & 26.35 & \\
\hline Range (min-max) & $23.88-31.22$ & 23.44-29.59 & \\
\hline Lama operasi (menit) & & & 0.068 \\
\hline Mean \pm Std & $69.44 \pm 5.393$ & $73.89 \pm 5.016$ & \\
\hline Median & 70.00 & 70.00 & \\
\hline Range (min-max) & $60.00-80.00$ & $70.00-85.00$ & \\
\hline Perdarahan (ml) & & & 0.308 \\
\hline Mean \pm Std & $419.44 \pm 59.752$ & $400.00 \pm 51.450$ & \\
\hline Median & 400.00 & 400.00 & \\
\hline Range (min-max) & $300.00-550.00$ & $300.00-500.00$ & \\
\hline Tinggi Blok & & & 1.000 \\
\hline T5 & $4(22.2 \%)$ & $3(16.7 \%)$ & \\
\hline T6 & $14(77.8 \%)$ & $15(83.3 \%)$ & \\
\hline Cairan Intraoperasi & & & 0.252 \\
\hline Mean \pm Std & $138.89 \pm 8.324$ & $134.44 \pm 11.991$ & \\
\hline Median & 140.00 & 130.00 & \\
\hline Range (min-max) & $130.00-150.00$ & $120.00-150.00$ & \\
\hline Lama Puasa & & & 0.424 \\
\hline$M e a n \pm S t d$ & $7.50 \pm 1.465$ & $7.28 \pm 1.074$ & \\
\hline Median & 8.00 & 7.00 & \\
\hline Range (min-max) & $4.00-10.00$ & $6.00-10.00$ & \\
\hline
\end{tabular}

Keterangan: untuk data numerik nilai $\mathrm{p}$ diuji dengan uji $\mathrm{T}$ tidak berpasangan apabila data berdsitribusi normal dengan alternatif uji Mann Whitney apabila data tidak berdistribusi normal. Data kategorik nilai p dihitung berdasarkan uji Chi-Square dengan alternative uji Kolmogorov Smirnov dan Exact Fisher apabila syarat dari Chi-Square tidak terpenuhi.. Nilai kemaknaan berdasarkan nilai $\mathrm{p}<0,05$.Tanda* menunjukkan nilai $\mathrm{p}<0,05$ artinya signifkan atau bermakna secara statistik. 
Tabel 2. Perbandingan Angka Kejadian Hipotensi pada Kedua Kelompok

\begin{tabular}{llll}
\hline Variabel & $\begin{array}{l}\text { Kelompok } \\
\text { Kontrol } \\
\mathrm{N}=18\end{array}$ & $\begin{array}{l}\text { Norepinefrin } \\
\mathrm{N}=18\end{array}$ & \\
\hline Kejadian & & & $0.002 *$ \\
Hipotensi & & & \\
Ya & $11(61,1 \%)$ & $2(11,1 \%)$ & \\
Tidak & & $16(88,9 \%)$ & \\
\hline
\end{tabular}

Keterangan: Data numerik nilai $\mathrm{p}$ diuji dengan uji $\mathrm{T}$ tidak berpasangan jika data berdsitribusi normal, dengan uji Mann Whitney jika data tidak berdistribusi normal. Data nilai p dihitung berdasarkan uji Chi-Square dengan uji Kolmogorov Smirnov dan Exact Fisher apabila syarat Chi-Square tidak terpenuhi. Nilai kemaknaan berdasarkan nilai $p<0,05$. Tanda* menunjukkan nilai $\mathrm{p}<0,05$ artinya signifkan atau bermakna secara statistik

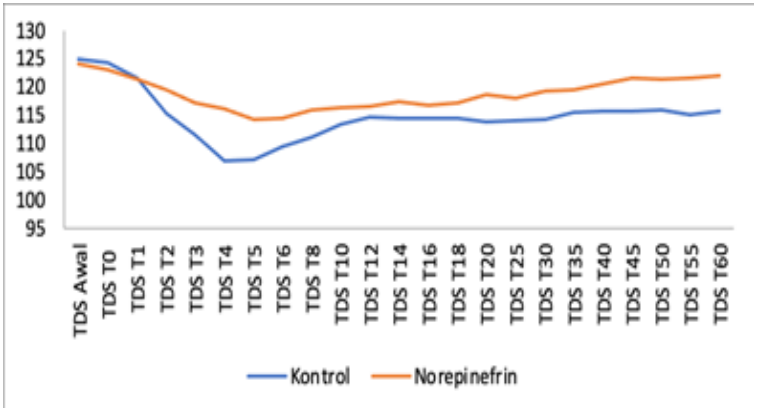

Gambar 1. Grafik Perbandingan Tekanan Darah Sistolik antara Kelompok Kontrol dan Kelompok Norepinefrin

pada kelompok penelitian diatas diperoleh informasi nilai $P$ pada variabel penurunan tekanan darah diastolik menit ke-5 hingga menit ke-60 lebih kecil dari 0.05 (nilai $\mathrm{p}<0.05$ ) yang

Tabel 3. Perbandingan Penurunan Tekanan Darah Sistolik (TDS) antara Kelompok Kontrol dan Kelompok Norepinefrin

\begin{tabular}{|c|c|c|c|}
\hline \multirow[t]{2}{*}{ Variabel } & \multicolumn{2}{|c|}{ Kelompok } & \multirow[t]{2}{*}{ Nilai $\mathrm{P}$} \\
\hline & Kontrol N=18 & Norepinefrin $\mathrm{N}=18$ & \\
\hline Penurunan TDS T0 & $0.78 \pm 0.808$ & $1.11 \pm 1.745$ & 0.719 \\
\hline Penurunan TDS T1 & $3.44 \pm 3.884$ & $2.72 \pm 3.594$ & 0.372 \\
\hline Penurunan TDS T2 & $9.72 \pm 14.547$ & $4.61 \pm 5.564$ & 0.481 \\
\hline Penurunan TDS T3 & $13.44 \pm 12.074$ & $7.00 \pm 4.814$ & 0.161 \\
\hline Penurunan TDS T4 & $18.00 \pm 11.345$ & $8.11 \pm 5.155$ & $0.003 * *$ \\
\hline Penurunan TDS T5 & $17.83 \pm 10.188$ & $10.00 \pm 7.292$ & $0.012 * *$ \\
\hline Penurunan TDS T6 & $15.56 \pm 8.473$ & $9.67 \pm 6.579$ & $0.019 * *$ \\
\hline Penurunan TDS T8 & $13.83 \pm 6.758$ & $8.28 \pm 4.968$ & $0.006 * *$ \\
\hline Penurunan TDS T10 & $11.61 \pm 5.731$ & $7.89 \pm 5.063$ & 0.051 \\
\hline Penurunan TDS T12 & $10.39 \pm 4.448$ & $7.56 \pm 4.890$ & 0.078 \\
\hline Penurunan TDS T14 & $10.44 \pm 4.076$ & $6.83 \pm 4.091$ & $0.012 * *$ \\
\hline Penurunan TDS T16 & $10.50 \pm 4.356$ & $7.33 \pm 5.258$ & 0.057 \\
\hline Penurunan TDS T18 & $10.56 \pm 5.044$ & $6.94 \pm 5.035$ & $0.039 * *$ \\
\hline Penurunan TDS T20 & $11.22 \pm 5.826$ & $5.61 \pm 4.913$ & $0.004 * *$ \\
\hline Penurunan TDS T25 & $10.89 \pm 4.751$ & $6.17 \pm 5.823$ & $0.012 * *$ \\
\hline Penurunan TDS T30 & $10.83 \pm 4.817$ & $5.00 \pm 4.690$ & $0.001 * *$ \\
\hline Penurunan TDS T35 & $9.56 \pm 4.805$ & $4.67 \pm 5.314$ & $0.004 * *$ \\
\hline Penurunan TDS T40 & $9.28 \pm 4.587$ & $3.67 \pm 4.550$ & $0.001 * *$ \\
\hline Penurunan TDS T45 & $9.22 \pm 4.660$ & $2.61 \pm 4.654$ & $0.0001 * *$ \\
\hline Penurunan TDS T50 & $9.00 \pm 5.434$ & $2.89 \pm 4.255$ & $0.0001 * *$ \\
\hline Penurunan TDS T55 & $9.89 \pm 7.584$ & $2.50 \pm 4.004$ & $0.001 * *$ \\
\hline Penurunan TDS T60 & $9.22 \pm 5.331$ & $2.11 \pm 4.283$ & $0.0001 * *$ \\
\hline
\end{tabular}

Keterangan: Untuk data numerik nilai p diuji dengan uji $\mathrm{T}$ tidak berpasangan apabila data berdsitribusi normal dengan alternatif uji Mann Whitney apabila data tidak berdistribusi normal..Nilai kemaknaan berdasarkan nilai $p<0,05$.Tanda* menunjukkan nilai $\mathrm{p}<0,05$ artinya signifkan atau bermakna secara statistik. 
Tabel 4. Perbandingan Penurunan Tekanan Darah Diastolik (TDD) antara Kelompok Kontrol dan Kelompok Norepinefrin

\begin{tabular}{|c|c|c|c|}
\hline \multirow[t]{2}{*}{ Variabel } & \multicolumn{2}{|c|}{ Kelompok } & \multirow[t]{2}{*}{ Nilai P } \\
\hline & Kontrol N=18 & Norepinefrin $\mathrm{N}=18$ & \\
\hline Penurunan TDD T0 & $0.94 \pm 1.662$ & $0.56 \pm 3.365$ & 0.521 \\
\hline Penurunan TDD T1 & $2.78 \pm 5.418$ & $0.72 \pm 3.801$ & 0.104 \\
\hline Penurunan TDD T2 & $5.28 \pm 6.515$ & $1.67 \pm 3.361$ & 0.091 \\
\hline Penurunan TDD T3 & $8.61 \pm 8.705$ & $3.22 \pm 4.223$ & 0.104 \\
\hline Penurunan TDD T4 & $11.72 \pm 9.467$ & $6.33 \pm 7.340$ & 0.065 \\
\hline Penurunan TDD T5 & $12.89 \pm 8.181$ & $6.11 \pm 6.773$ & $0.011 * *$ \\
\hline Penurunan TDD T6 & $12.28 \pm 7.925$ & $6.39 \pm 6.581$ & $0.021^{* *}$ \\
\hline Penurunan TDD T8 & $12.89 \pm 6.910$ & $6.33 \pm 5.168$ & $0.003 * *$ \\
\hline Penurunan TDD T10 & $12.56 \pm 6.167$ & $6.83 \pm 5.032$ & $0.004 * *$ \\
\hline Penurunan TDD T12 & $12.56 \pm 5.953$ & $7.11 \pm 5.697$ & $0.008 * *$ \\
\hline Penurunan TDD T14 & $13.89 \pm 5.465$ & $7.00 \pm 4.485$ & $0.0001 * *$ \\
\hline Penurunan TDD T16 & $13.67 \pm 6.078$ & $6.72 \pm 5.655$ & $0.001 * *$ \\
\hline Penurunan TDD T18 & $14.06 \pm 6.611$ & $4.56 \pm 5.617$ & $0.0001 * *$ \\
\hline Penurunan TDD T20 & $13.94 \pm 6.357$ & $4.06 \pm 6.37$ & $0.0001 * *$ \\
\hline Penurunan TDD T25 & $14.89 \pm 6.230$ & $4.00 \pm 5.931$ & $0.0001 * *$ \\
\hline Penurunan TDD T30 & $13.50 \pm 6.299$ & $2.72 \pm 8.414$ & $0.0001 * *$ \\
\hline Penurunan TDD T35 & $12.28 \pm 6.676$ & $4.39 \pm 5.596$ & $0.001^{* *}$ \\
\hline Penurunan TDD T40 & $11.44 \pm 6.784$ & $3.28 \pm 6.479$ & $0.001^{* *}$ \\
\hline Penurunan TDD T45 & $11.00 \pm 8.331$ & $2.83 \pm 5.783$ & $0.002 * *$ \\
\hline Penurunan TDD T50 & $9.17 \pm 9.141$ & $3.11 \pm 5.335$ & $0.022 * *$ \\
\hline Penurunan TDD T55 & $10.17 \pm 8.376$ & $1.67 \pm 5.901$ & $0.001 * *$ \\
\hline Penurunan TDD T60 & $9.89 \pm 8.123$ & $2.44 \pm 5.415$ & $0.003 * *$ \\
\hline
\end{tabular}

Keterangan: Untuk data numerik nilai $\mathrm{p}$ diuji dengan uji T tidak berpasangan apabila data berdsitribusi normal dengan alternatif uji Mann Whitney apabila data tidak berdistribusi normal..Nilai kemaknaan berdasarkan nilai $p<0,05$.Tanda* menunjukkan nilai $\mathrm{p}<0,05$ artinya signifkan atau bermakna secara statistik

berarti signifikan atau bermakna secara statistik, dengan demikian dapat dijelaskan bahwa terdapat perbedaan rerata yang signifikan secara statistik antara variabel tersebut pada kelompok kontrol dan norepinefrin. Sedangkan nilai P pada variabel penurunan tekanan darah diastolik menit ke-0 sampai menit ke-4 lebih besar dari 0.05 (nilai $\mathrm{p}>0.05$ ) yang berarti tidak signifikan atau tidak bermakna secara statistik. Dengan demikian dapat dijelaskan bahwa terdapat mayoritas perbedaan rerata yang signifikan secara statistik pada TDD antara kelompok kontrol dan norepinefrin. Perbandingan penurunan Tekanan Arteri Rerata/ Mean Arterial Pressure (MAP) antara kelompok kontrol dan kelompok norepinefrin sejak sebelum induksi, menit awal sampai dengan operasi selesai tergambar pada Tabel 4.6 dan Gambar 4.3. Hasil uji statistika pada kelompok penelitian diatas diperoleh informasi nilai $\mathrm{P}$ pada variabel penurunan MAP menit ke-3 sampai dengan menit ke-60 lebih kecil dari 0.05 (nilai $\mathrm{p}<0.05$ ) yang berarti bermakna secara statistik, dengan demikian dapat dijelaskan bahwa terdapat perbedaan rerata yang signifikan secara statistik antara variabel tersebut pada kelompok kontrol dan norepinefrin.

Sedangkan nilai $\mathrm{P}$ pada variabel penurunan MAP menit ke-0 hingga menit ke-2 lebih besar dari 0.05 (nilai $\mathrm{p}>0.05$ ) yang berarti tidak bermakna 
Tabel 5. Perbandingan Tekanan Arteri Rerata (Mean Arterial Pressure/ MAP) antara Kelompok Kontrol dan Kelompok Norepinefrin

\begin{tabular}{|c|c|c|c|}
\hline \multirow[t]{2}{*}{ Variabel } & \multicolumn{2}{|c|}{ Kelompok } & \multirow[t]{2}{*}{ Nilai $\mathrm{P}$} \\
\hline & Kontrol $\mathrm{N}=18$ & Norepinefrin $\mathrm{N}=18$ & \\
\hline Penurunan MAP T0 & $1.11 \pm 1.132$ & $0.67 \pm 2.449$ & 0.913 \\
\hline Penurunan MAP T1 & $3.06 \pm 4.478$ & $1.44 \pm 3.110$ & 0.126 \\
\hline Penurunan MAP T2 & $6.94 \pm 9.065$ & $2.56 \pm 3.312$ & 0.143 \\
\hline Penurunan MAP T3 & $10.83 \pm 9.357$ & $4.39 \pm 3.760$ & $0.024 * *$ \\
\hline Penurunan MAP T4 & $13.89 \pm 9.573$ & $6.72 \pm 5.969$ & $0.044 * *$ \\
\hline Penurunan MAP T5 & $14.22 \pm 7.923$ & $7.33 \pm 6.399$ & $0.007 * *$ \\
\hline Penurunan MAP T6 & $13.50 \pm 7.278$ & $7.33 \pm 6.136$ & $0.010 * *$ \\
\hline Penurunan MAP T8 & $13.22 \pm 6.122$ & $6.89 \pm 4.651$ & $0.001 * *$ \\
\hline Penurunan MAP T10 & $12.22 \pm 5.140$ & $7.00 \pm 4.187$ & $0.002 * *$ \\
\hline Penurunan MAP T12 & $11.94 \pm 4.608$ & $7.11 \pm 4.337$ & $0.003 * *$ \\
\hline Penurunan MAP T14 & $13.00 \pm 3.865$ & $6.83 \pm 3.468$ & $0.0001 * *$ \\
\hline Penurunan MAP T16 & $12.83 \pm 4.554$ & $6.78 \pm 4.857$ & $0.0001 * *$ \\
\hline Penurunan MAP T18 & $12.94 \pm 5.286$ & $5.22 \pm 4.622$ & $0.0001 * *$ \\
\hline Penurunan MAP T20 & $13.06 \pm 5.011$ & $4.44 \pm 4.718$ & $0.0001 * *$ \\
\hline Penurunan MAP T25 & $13.33 \pm 4.537$ & $4.67 \pm 4.911$ & $0.0001 * *$ \\
\hline Penurunan MAP T30 & $12.50 \pm 4.719$ & $3.33 \pm 6.399$ & $0.0001 * *$ \\
\hline Penurunan MAP T35 & $11.50 \pm 5.227$ & $4.33 \pm 5.122$ & $0.0001 * *$ \\
\hline Penurunan MAP T40 & $11.00 \pm 5.531$ & $3.28 \pm 5.312$ & $0.0001 * *$ \\
\hline Penurunan MAP T45 & $10.39 \pm 6.040$ & $2.67 \pm 4.715$ & $0.0001 * *$ \\
\hline Penurunan MAP T50 & $9.22 \pm 6.752$ & $3.06 \pm 4.595$ & $0.003 * *$ \\
\hline Penurunan MAP T55 & $10.22 \pm 6.783$ & $1.78 \pm 4.346$ & $0.0001 * *$ \\
\hline Penurunan MAP T60 & $9.83 \pm 5.512$ & $2.22 \pm 4.910$ & $0.0001 * *$ \\
\hline
\end{tabular}

Keterangan: untuk data numerik nilai $\mathrm{p}$ diuji dengan uji $\mathrm{T}$ tidak berpasangan apabila data berdsitribusi normal dengan alternatif uji Mann Whitney apabila data tidak berdistribusi normal. Nilai kemaknaan berdasarkan nilai $\mathrm{p}<0,05$.Tanda* menunjukkan nilai $\mathrm{p}<0,05$ artinya signifkan atau bermakna secara statistik

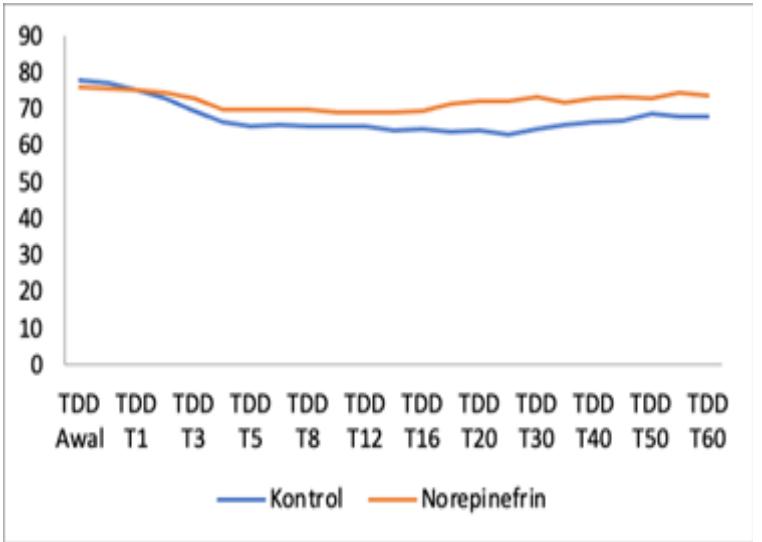

Gambar 2. Grafik Perbandingan Tekanan Darah Diastolik antara Kelompok Kontrol dan Kelompok Norepinefrin

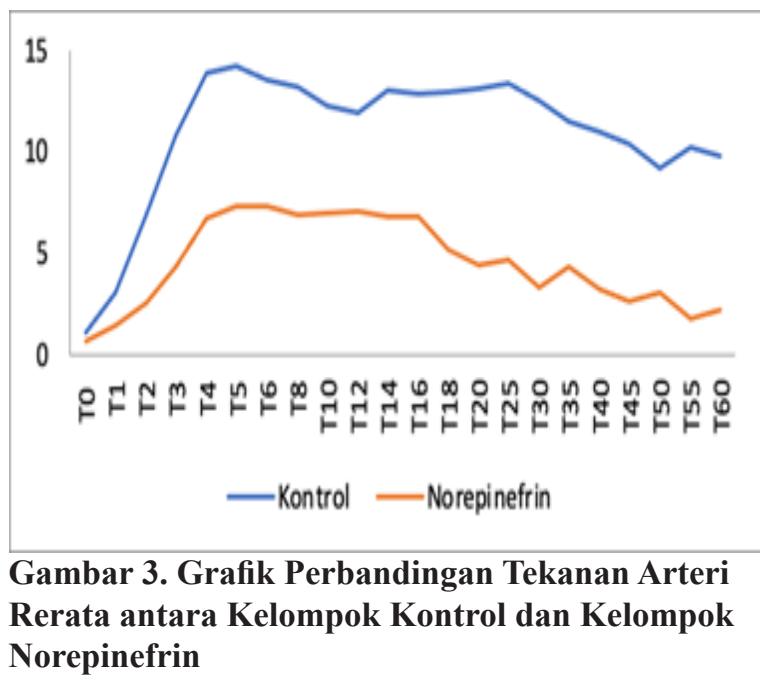


Tabel 6. Perbandingan Linear Analog Scale (LAS) antara Kelompok Kontrol dan Kelompok Norepinefrin

\begin{tabular}{llll}
\hline \multicolumn{1}{c}{ Variabel } & \multicolumn{2}{c}{ Kelompok } & Nilai P \\
& \multicolumn{1}{c}{$\begin{array}{c}\text { Kontrol } \\
\mathrm{N}=18\end{array}$} & \multicolumn{1}{c}{$\begin{array}{c}\text { Norepinefrin } \\
\mathrm{N}=18\end{array}$} \\
\hline Kategori Skor LAS T1 & & 1.000 \\
$>6$ & $0(0.0 \%)$ & $0(0.0 \%)$ & \\
$\leq 6$ & $18(100.0 \%)$ & $18(100.0 \%)$ & $0.015^{* *}$ \\
Kategori Skor LAS T3 & & & \\
$>6$ & $8(44.4 \%)$ & $15(83.3 \%)$ & 0.603 \\
$\leq 6$ & $10(55.6 \%)$ & $3(16.7 \%)$ & \\
Kategori Skor LAS T6 & & & 1.000 \\
$>6$ & $15(83.3 \%)$ & $17(94.4 \%)$ & \\
$\leq 6$ & $3(16.7 \%)$ & $1(5.6 \%)$ & \\
Kategori Skor LAS T9 & & & \\
$>6$ & $18(100.0 \%)$ & $18(100.0 \%)$ & \\
$\leq 6$ & $0(0.0 \%)$ & $0(0.0 \%)$ & \\
\hline
\end{tabular}

Keterangan: untuk data numerik nilai $\mathrm{p}$ diuji dengan uji $\mathrm{T}$ tidak berpasangan apabila data berdsitribusi normal dengan alternatif uji Mann Whitney apabila data tidak berdistribusi normal..Nilai kemaknaan berdasarkan nilai $\mathrm{p}<0,05$.Tanda* menunjukkan nilai $\mathrm{p}<0,05$ artinya signifkan atau bermakna secara statistik

Tabel 7. Perbandingan Laju Nadi antara Kelompok Kontrol dan Kelompok Norepinefri

\begin{tabular}{lccl}
\hline \multicolumn{1}{c}{ Variabel } & \multicolumn{2}{c}{ Kelompok } & Nilai P \\
& $\mathrm{N}=18$ & $\begin{array}{c}\text { Norepinefrin } \\
\mathrm{N}=18\end{array}$ & \\
\hline Laju Nadi Awal & $89.44 \pm 7.374$ & $90.78 \pm 8.200$ & 0.611 \\
Laju Nadi T0 & $89.11 \pm 6.416$ & $89.39 \pm 8.081$ & 0.910 \\
Laju Nadi T1 & $88.06 \pm 5.070$ & $88.44 \pm 7.633$ & 0.858 \\
Laju Nadi T2 & $87.00 \pm 5.750$ & $87.39 \pm 8.431$ & 0.873 \\
Laju Nadi T3 & $88.22 \pm 5.128$ & $86.56 \pm 8.672$ & 0.488 \\
Laju Nadi T4 & $88.78 \pm 5.847$ & $85.94 \pm 8.855$ & 0.265 \\
Laju Nadi T5 & $89.06 \pm 7.596$ & $85.22 \pm 8.889$ & 0.173 \\
Laju Nadi T6 & $88.61 \pm 8.486$ & $84.56 \pm 8.753$ & 0.167 \\
Laju Nadi T8 & $86.67 \pm 7.911$ & $83.72 \pm 9.093$ & 0.307 \\
Laju Nadi T10 & $85.39 \pm 8.465$ & $83.89 \pm 8.498$ & 0.599 \\
Laju Nadi T12 & $85.06 \pm 7.989$ & $82.50 \pm 8.893$ & 0.371 \\
Laju Nadi T14 & $83.61 \pm 8.596$ & $82.06 \pm 7.989$ & 0.578 \\
Laju Nadi T16 & $83.17 \pm 7.980$ & $81.11 \pm 7.638$ & 0.435 \\
Laju Nadi T18 & $83.28 \pm 6.649$ & $80.28 \pm 7.775$ & 0.222 \\
Laju Nadi T20 & $82.72 \pm 6.910$ & $80.11 \pm 8.167$ & 0.308 \\
\hline
\end{tabular}

Keterangan: untuk data numerik nilai $\mathrm{p}$ diuji dengan uji $\mathrm{T}$ tidak berpasangan apabila data berdsitribusi normal dengan alternatif uji Mann Whitney apabila data tidak berdistribusi normal. Nilai kemaknaan berdasarkan nilai $\mathrm{p}<0,05$. Tanda* menunjukkan nilai $\mathrm{p}<0,05$ artinya signifkan atau bermakna secara statistik 
Tabel 7b. Perbandingan Laju Nadi antara Kelompok Kontrol dan Kelompok Norepinefrin

\begin{tabular}{lccc}
\hline Variabel & \multicolumn{2}{c}{ Kelompok } & Nilai P \\
& Kontrol & Norepinefrin & \\
& $\mathrm{N}=18$ & $\mathrm{~N}=18$ & \\
\hline Laju Nadi T25 & $82.11 \pm 6.738$ & $79.78 \pm 8.606$ & 0.371 \\
Laju Nadi T30 & $82.44 \pm 6.224$ & $79.17 \pm 8.833$ & 0.207 \\
Laju Nadi T35 & $81.94 \pm 6.855$ & $78.28 \pm 9.423$ & 0.191 \\
Laju Nadi T40 & $81.94 \pm 7.025$ & $77.67 \pm 9.834$ & 0.142 \\
Laju Nadi T45 & $81.39 \pm 7.047$ & $77.39 \pm 9.494$ & 0.160 \\
Laju Nadi T50 & $80.11 \pm 6.333$ & $77.94 \pm 9.914$ & 0.440 \\
Laju Nadi T55 & $80.28 \pm 6.884$ & $77.50 \pm 9.231$ & 0.339 \\
Laju Nadi T60 & $80.56 \pm 7.318$ & $76.89 \pm 9.330$ & 0.198 \\
\hline
\end{tabular}

Keterangan: untuk data numerik nilai $\mathrm{p}$ diuji dengan uji $\mathrm{T}$ tidak berpasangan apabila data berdsitribusi normal dengan alternatif uji Mann Whitney apabila data tidak berdistribusi normal. Nilai kemaknaan berdasarkan nilai $\mathrm{p}<0,05$. Tanda* menunjukkan nilai $\mathrm{p}<0,05$ artinya signifkan atau bermakna secara statistik

Tabel 8. Perbandingan Nilai APGAR antara Kelompok Kontrol dan Kelompok Norepinefrin

\begin{tabular}{|c|c|c|c|}
\hline \multirow[t]{2}{*}{ Variabel } & \multicolumn{2}{|l|}{ Kelompok } & \multirow[t]{2}{*}{ Nilai P } \\
\hline & $\begin{array}{l}\text { Kontrol } \\
\mathrm{N}=18\end{array}$ & $\begin{array}{l}\text { Norepinefrin } \\
\mathrm{N}=18\end{array}$ & \\
\hline $\begin{array}{l}\text { Skor } \\
\text { APGAR } \\
\text { T1 }\end{array}$ & $4.33 \pm 1.534$ & $4.22 \pm 1.555$ & 0.815 \\
\hline $\begin{array}{l}\text { Skor } \\
\text { APGAR } \\
\text { T5 }\end{array}$ & $6.89 \pm 1.183$ & $6.94 \pm 1.162$ & 0.839 \\
\hline
\end{tabular}

Keterangan: untuk Data kategorik nilai $\mathrm{p}$ dihitung berdasarkan uji Chi-Square dengan alternative uji Kolmogorov Smirnov dan Exact Fisher apabila syarat dari Chi-Square tidak terpenuhi..Nilai kemaknaan berdasarkan nilai $p<0,05$. Tanda* menunjukkan nilai $\mathrm{p}<0,05$ artinya signifkan atau bermakna secara statistik.

secara statistik. Sehingga dapat dijelaskan bahwa terdapat mayoritas perbedaan rerata yang signifikan pada MAP antara kelompok kontrol dan norepinefrin. Kontraksi uterus antara kelompok kontrol dan kelompok norepinefrin digambarkan dengan LAS yang digambarkan pada Tabel 4.7 dan Gambar 4.4. Pada 3 menit pertama, nilai LAS $>6$ pada kelompok norepinefrin ditemukan sebanyak 15 dari total 18 pasien sedangkan pada kelompok kontrol sebanyak 8 dari total 18 pasien. Setelah dilakukan penghitungan secara statistik,

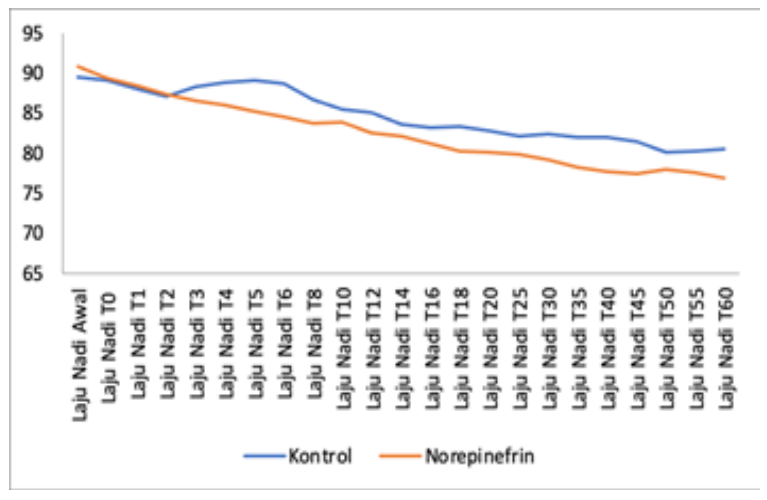

Gambar 5. Grafik Perbandingan Laju Nadi antara Kelompok Kontrol dan Kelompok Norepinefrin

didapatkan nilai $\mathrm{p}=0,015$ yang berarti terdapat perbedaan yang bermakna antara kelompok kontrol dan norepinefrin.

Hal ini menunjukkan kelompok norepienfrin dapat mencapai kontraksi uterus yang adekuat lebih cepat (LAS > 6) dibandingkan dengan kelompok kontrol. Walaupun tidak terdapat perbedaan secara bermakna jumlah pasien dengan LAS $>6$ pada menit ke- 6 dan ke-9, bila rata-rata nilai LAS dihitung secara terperinci, terdapat kontraksi uterus (nilal LAS) yang lebih baik pada kelompok norepinefrin dibandingkan kelompok kontrol yang secara statistik bermakna $(p<0,05)$. Perbandingan laju nadi antara kelompok kontrol dan kelompok norepinefrin sejak sebelum 
induksi, menit awal sampai dengan operasi selesai tergambar pada Tabel 4.8 dan gambar 4.5. Laju nadi rerata pada kelompok norepinefrin lebih rendah tetapi tidak menunjukkan perbedaan bermakna terhadap kelompok kontrol dengan nilai $p>0,05$ sebelum induksi hingga menit ke60. Tidak ditemukan bradikardi pada subjek penelitian dan tidak ada pasien yang memerlukan sulfas atropin. Perbandingan nilai APGAR antara kelompok kontrol dan kelompok norepinefrin tergambar pada Tabel 4.9. Nilai APGAR antara kedua kelompok tidak menunjukkan perbedaan yang secara statistik bermakna yang ditunjukkan dengan nilai $\mathrm{p}>0,05$.

\section{Pembahasan}

Pencegahan dan pengobatan hipotensi maternal yang terjadi akibat anestesi spinal pada seksio sesarea masih menjadi masalah. Beberapa penelitian telah dilakukan untuk mencegah komplikasi hipotensi sehingga dapat menghasilkan metode yang baik untuk menghindari kejadian tersebut. Tindakan yang dapat dilakukan untuk mencegah terjadinya hipotensi adalah pemberian cairan, obat-obatan, mengurangi dosis anestesi lokal, serta tindakan secara mekanis seperti memposisikan pasien. Pemberian cairan dengan cairan infus intravena sebelum tindakan anestesi spinal bertujuan untuk meningkatkan volume intravaskular. Obatobatan yang biasanya diberikan adalah obat vasopresor seperti norepinefrin, epinefrin, dan penilepinefrin. $^{2}$

Pemberian infus intravena untuk meningkatkan volume intravaskular dan mencegah hipotensi pada anestesi spinal dapat diberikan sebagai preloading atau coloading. Secara umum, cairan infus terdiri dari dua jenis yaitu cairan koloid dan kristaloid. Berdasarkan penelitian sebelumnya di Prancis pada tahun 2012, pemberian cairan kristaloid memiliki efek minimal dalam pecegahan hipotensi spinal jika dibandingkan dengan koloid. ${ }^{5}$ Penelitian serupa di Iran tahun 2012 menunjukkan tidak ada perbedaan signifikan dalam pencegahan hipotensi pada pemberian kristaloid atau koloid namun ditemukan efek samping bradikardi, hipertensi, dan mual muntah yang lebih kecil pada koloid. ${ }^{6}$ Penelitian lain di India pada tahun 2013 menunjukkan bahwa preloading dan coloading sama-sama efektif dalam menurunkan kejadian hipotensi dimana koloid lebih efisien dibandingkan kristaloid terutama pada preloading. Hasil ini berkaitan dengan waktu paruh koloid di kompartemen intravaskular lebih lama sehingga mampu meningkatkan volume intravaskular untuk durasi yang lebih lama dibandingkan kristaloid yang hanya bertahan selama satu jam. ${ }^{2}$

Penelitian pada tahun 2018 membandingkan efektivitas preloading cairan kristaloid dan koloid dalam menurunkan kejadian hipotensi dan komplikasinya pada wanita yang menjalani seksio sesarea elektif. Hasilnya adalah persentase penurunan tekanan darah sistol dan diastol pada penggunaan cairan kristaloid lebih tinggi secara signifikan dibandingkan cairan koloid $(\mathrm{p}=$ 0,042 dan $\mathrm{p}=0,008$ ). Prevalensi mual muntah didapatkan lebih rendah pada penggunaan koloid dibandingkan kristaloid, tetapi hasilnya tidak signifikan secara statistik. Skor APGAR juga didapatkan tidak berbeda secara signifikan pada penggunaan kedua cairan tersebut. Oleh karena itu, penelitian tersebut merekomendasikan penggunaan preloading cairan koloid untuk mencegah instabilitas hemodinamik akibat anestesi spinal pada prosedur seksio sesarea. ${ }^{7}$

Penelitian ini melibatkan 36 pasien yang menjalani operasi seksio sesarea dengan anestesi spinal. Berdasarkan data karakteristik subjek penelitian (Tabel 4.1) tidak didapatkan perbedaan bermakna antara kelompok kontrol dan norepinefrin dalam hal umur, tinggi badan, berat badan, BMI, lama operasi, lama puasa, tinggi blok dan pemberian cairan preloading sehingga menunjukkan bahwa subjek penelitian ini relatif homogen secara statistik $(p>0,05)$ dan kedua kelompok layak untuk diperbandingkan. Penelitian ini membandingkan kelompok yang diberikan norepinefrin dibandingkan dengan kelompok kontrol. Kelompok norepinefrin mendapatkan NE bolus sebanyak 5 mcg intravena yang dilanjutkan dengan rumatan $0,05 \mathrm{mcg} / \mathrm{kg} /$ menit intravena. Dosis pada penelitian ini sesuai dengan penelitian sebelumnya di Hongkong 
tahun 2018 yang membandingkan pemberian norepinefrin dosis 0,05 dan $0,075 \mathrm{mcg} / \mathrm{kg} / \mathrm{menit}$ dimana didapatkan perbedaan antara kedua dosis hanya peningkatan TDS sebesar $5 \mathrm{mmHg}$ yang tidak bermakna secara statistik. Berdasarkan penelitian tersebut, dosis terbaik NE untuk anestesi spinal pada seksio sesarea adalah 0,05 $\mathrm{mcg} / \mathrm{kg} /$ menit untuk menjaga curah jantung ibu dan perfusi uteroplasenta. Penelitian tersebut juga menunjukkan bahwa pemberian norepinefrin secara kontinu lebih efektif dalam menjaga tekanan darah dan curah jantung ibu. Menjaga curah jantung ibu tercukupi sangat penting, terutama pada kasus risiko tinggi. ${ }^{4,9,10}$

Penelitian di Cina pada tahun 2018 membandingkan efikasi dan safety tiga regimen dosis NE, yaitu 5, 10, dan 15 mikrogram/ $\mathrm{kg} / \mathrm{h}$ untuk mencegah hipotensi akibat anestesi spinal pada seksio sesarea. Penelitian tersebut menyimpulkan bahwa NE 5-10 mikrogram/ $\mathrm{kg} / \mathrm{h}$ menurunkan insidensi hipotensi serta lebih baik dalam mempertahankan stabilitas hemodinamik pada saat anestesi spinal seksio sesarea berlangsung. Sementara regimen dosis NE tertinggi (15 mikrogram $/ \mathrm{kg} / \mathrm{h}$ ) menyebabkan episode hipertensi. ${ }^{9}$

Penelitian membandingkan efektivitas NE 0,05 mikrogram $/ \mathrm{kg} /$ menit dan Penileprin 0,1 mikrogram $/ \mathrm{kg} /$ menit dalam menurunkan kebutuhan intervensi bolus PEn 100 mikrogram atau efedrin $5 \mathrm{mg}$ untuk mempertahankan tekanan darah pada anestesi spinal seksio sesarea. Dosis tersebut setara dengan NE 3 mikrogram/menit dan PEn 6 mikrogram/menit. Kesimpulannya adalah NE memiliki efikasi yang lebih bagus dalam mencegah hipotensi sehingga dapat dipertimbangkan sebagai alternatif PEn pada anestesi spinal seksio sesarea. ${ }^{10}$ Hasil penelitian ini menunjukkan bahwa penurunan tekanan darah yang digambarkan dengan TDS dan MAP pada kelompok kontrol lebih besar dengan mencapai $>20 \%$ nilai baseline jika dibandingkan dengan kelompok norepinefrin. Hal ini menggambarkan bahwa pemberian profilaksis norepinefrin pada pasien yang menjalani anestesi apinal pada operasi seksio sesarea dapat menghasilkan penurunan tekanan darah yang lebih kecil. Hasil ini bermakna baik secara statistik dan secara klinis karena ditemukan lebih sedikit penurunan tekanan darah hingga $>20 \%$ baseline pada kelompok norepinefrin yang menunjukkan berkurangnya kejadian hipotensi yang dapat merugikan pasien. Hasil ini sesuai dengan studi fisiologis di Amerika pada tahun 2015 bahwa vasopresor alfa agonis merupakan vasopresor yang paling dapat diandalkan untuk mencegah dan mengatasi hipotensi akibat anestesi spinal pada seksio sesarea. ${ }^{11}$

Secara umum pemberian efedrin merupakan pilihan pertama dalam menjaga tekanan darah ibu ketika prosedur anastesi spinal pada seksio sesarea, karena efeknya dalam merangsang alfa dan beta adrenergik reseptor. Norepinefrin memiliki efek kuat untuk alfa adrenergik dan lemah pada beta adrenergik. Atas dasar tersebut, norepinefrin lebih sesuai dalam menjaga tekanan darah karena efek kronotropik yang lebih rendah. Penelitian di Mesir tahun 2018 membandingkan pemberian profilaksis bolus NE 5 mikrogram dan ephedrine 10 miligram. Hasil penelitian tersebut yaitu jumlah hipotensi dan hipertensi serta frekuensi bradikardi dan takikardi secara signifikan lebih rendah pada kelompok NE dibandingkan dengan $\mathrm{PE}(\mathrm{P}=0,02$ 0,003, 0,0002, dan 0,008). Indeks denyut arteri uterus lebih rendah pada grup $\mathrm{NE}$ dibandingkan dengan $\mathrm{PE}$ $(\mathrm{P}=0,01)$ diukur 5 menit setelah anastesi spinal. Kesimpulan dari penelitian tersebut yaitu NE lebih cocok dan poten untuk menyeimbangkan efek hemodinamik anastesi spinal ketika persalinan seksio sesarea. Hasil penelitian ini juga sesuai dengan penelitian sebelumnya pada tahun 2015 di Mesir dan 2018 di Iran yang menyatakan bahwa norepinefrin lebih unggul dibandingkan efedrin dalam penurunan kejadian hipotensi pada anestesi spinal pada seksio sesarea. Hal ini sesuai dengan rasio potensi antara norepinefrin dan efedrin yaitu $1.000: 1 .^{11.12}$

Vasopresor bertujuan untuk mencegah hipotensi yang mungkin terjadi setelah pemberian anestesi spinal pada seksio sesarea. Pada keadaan hipotensi, pemberian vasopresor simpatomimetik yang bertujuan untuk menjaga tonus arteri dan tekanan arteri menjadi hal terpenting untuk keamanan dari anastesi spinal. Dari beberapa 
penelitian yang telah dipaparkan, norepinefrin merupakan pilihan vasopresor yang tepat karena efeknya yang kuat pada alfa adrenergik dan lemah pada beta adrenergik sehingga dapat dipertimbangkan menjadi alternatif dalam anestesi spinal pada prosedur seksio sesarea. ${ }^{10-13}$ Norepinefrin berperan pada adrenergik reseptor di otot halus uterus. Perannya pada $\beta$-adrenergik menyebabkan stimulasi dari adenilat siklase, menyebabkan peningkatan level cAMP, yang akan mengubah aktivitas cAMP-dependent protein kinase menjadi mirip dengan cGMP, dan menyebabkan relaksasi dari otot halus uterus. Secara kontras, aktivasi dari $\alpha$-adrenergik reseptor menyebabkan influks dari kalsium melalui reseptor $\mathrm{Ca} 2+$ dan menyebabkan keluarnya kalsium IP3-mediated dari retikulum sarkoplasmik, sehingga menyebabkan kontraksi myometrium. ${ }^{14-16}$ Aktivitas obat ini bersifat $\alpha$-adrenergik yang kuat dengan tambahan agonis $\beta$-adrenergik lemah, sehingga efek yang akan ditimbulkan adalah peningkatan kontraksi miometrium serta meningkatkan kontraksi uterus. $^{16-18}$

Pada penelitian ini, didapatkan kontraksi uterus yang lebih baik secara bermakna pada kelompok norepinefrin dibandingkan dengan kelompok kontrol. Pengukuran kontraksi uterus pada penelitian ini diukur dengan menggunakan LAS. Penilaian dilakukan dengan cara palpasi uterus oleh dokter spesialis obstetri dan ginekologi. LAS diukur sesaat setelah tali pusat diklem (menit ke0) dan plasenta lahir kemudian dilanjutkan setiap 3 menit selama 15 menit. Penilaian kontraksi uterus dinilai dengan skala 0 hingga 10 . LAS 0 menunjukkan tidak adanya kontraksi uterus sama sekali, sementara LAS 10 berarti uterus berkontrasi penuh. ${ }^{19}$ LAS $\leq 6$ menunjukkan kontraksi uterus yang kurang optimal sehingga membutuhkan tambahan obat-obat uterotonik. Hasil ini karena norepinefrin memiliki efek agonis terhadap reseptor alfa dan beta adrenergik di otot halus uterus. Efek agonis alfa menyebabkan influx kalsium pada miometrium yang menyebabkan keluarnya kalsium dari retikulum sarkoplasmik sehingga terjadi kontraksi myometrium. Efek agonis beta menyebabkan stimulasi adenilat siklase, peningkatan cAMP dan mengubah aktivitas cAMP-dependent protein kinase yang menyebabkan relaksasi otot halus uterus. Norepinefrin dan efedrin memiliki efek agonis terhadap alfa yang kuat namun NE memiliki efek agonis beta yang lebih lemah dibandingkan efedrin sehingga kontraksi uterus yang ditimbulkan lebih kuat. ${ }^{14-16}$ Aspek keselamatan dari pemberian NE pada kasus obstetri juga sering dilakukan analisa termasuk dalam efek samping pada bayi seperti penilaian skor APGAR. Pada penelitian ini, tidak ditemukan perbedaan nilai APGAR yang bermakna antara kedua kelompok dengan nilai $\mathrm{P}>0.05$. Hal ini sesuai dengan penelitian yang sebelumnya yang menunjukkan tidak ditemukannya perbedaan nilai APGAR pada pasien yang mendapatkan norepinefrin dengan yang tidak mendapatkan vasopresor. ${ }^{7-9}$ Pada penelitian ini tidak didapatkan perubahan laju nadi yang bermakna antara kelompok kontrol dan kelompok norepinefrin. Hasil ini sama dengan penelitian sebelumnya yang menunjukkan tidak didapatkan perbedaan bermakna pada laju nadi antara pasien yang mendapat efedrin dan norepinefrin. ${ }^{20}$

\section{Simpulan}

Pemberian profilaksis noreprinefrin kontinu dapat mencegah dan menurunkan angka kejadian hipotensi pascaspinal anestesi dan meningkatkan kontraktilitas uterus pada pasien yang menjalani seksio sesaria. Pemberian norepinefrin kontinu tidak berpengaruh pada penilaian skor APGAR bayi dan tidak berpengaruh pada laju nadi ibu pada seksio sesarea dengan anestesi spinal.

\section{Daftar Pustaka}

1. Ahmed H, Hossam M, Adel A. Volume preload versus ephedrine infusion for prevention of hypotension due to spinal anesthesia for cesarean section. Open J Anesthesiol. 2016;06:37-44.

2. Bajwa SJS, Kulshrestha A, Jindal R. Coloading or pre-loading for prevention of hypotension after spinal anaesthesia! a therapeutic dilemma. Anesth Essays Res. 2013;7(2):155-9. 
3. Hasanin AM, Amin SM, Agiza NA, Elsayed MK, Refaat S, Hussein HA, et al. Norepinephrine infusion for preventing postspinal anesthesia hypotension during cesarean delivery: a randomized dose-finding trial. Anesthesiology. 2019;130(1):55-62.

4. Ngan Kee WD, Lee SWY, Ng FF, Khaw KS. Prophylactic norepinephrine infusion for preventing hypotension during spinal anesthesia for cesarean delivery. Anesthesia and Analgesia. 2018;126(6):1989-94.

5. Mercier FJ. Cesarean delivery fluid management. Current opinion in anaesthesiology. 2012;25(3):286-91.

6. Jabalameli M, Soltani HA, Hashemi J, Behdad S, Soleimani B. Prevention of post-spinal hypotension using crystalloid, colloid and ephedrine with three different combinations: a double blind randomized study. Adv Biomed Res. 2012;1:36-.

7. Gousheh MR, Akhondzade R, Aghahoseini HA, Olapour A, Rashidi MJA, medicine p. The effects of pre-spinal anesthesia administration of crystalloid and colloid solutions on hypotension in elective cesarean section. 2018;8(4).

8. Dong L, Dong Q, Song X, Liu Y, Wang YJIJCEM. Comparison of prophylactic bolus norepinephrine and phenylephrine on hypotension during spinal anesthesia for cesarean section. 2017;10(8):12315-21.

9. Chen D, Qi X, Huang X, Xu Y, Qiu F, Yan $Y$, et al. Efficacy and safety of different norepinephrine regimens for prevention of spinal hypotension in cesarean section: a randomized trial. BioMed research international. 2018;2018:2708175.

10. Vallejo MC, Attaallah AF, Elzamzamy OM, Cifarelli DT, Phelps AL, Hobbs GR, et al. An open-label randomized controlled clinical trial for comparison of continuous phenylephrine versus norepinephrine infusion in prevention of spinal hypotension during cesarean delivery. International journal of obstetric anesthesia. 2017;29:18-25.

11. Carvalho B, Dyer RA. Norepinephrine for spinal hypotension during cesarean delivery: another paradigm shift. Anesthesiology. 2015;122(4): 728-30.

12. Elnabtity AMA, Selim MF. Norepinephrine versus ephedrine to maintain arterial blood pressure during spinal anesthesia for cesarean delivery: a prospective double-blinded trial. Anesthesia, essays and researches. 2018;12(1):92.

13. Wang $\mathrm{X}$, Mao $\mathrm{M}$, Liu $\mathrm{S}$, Xu S, Yang JJMsmimjoe, research c. A comparative study of bolus norepinephrine, phenylephrine, and ephedrine for the treatment of maternal hypotension in parturients with preeclampsia during cesarean delivery under spinal anesthesia. 2019;25:1093.

14. Hall J. Pregnancy and Lactation. Guyton and Hall textbook of medical physiology. 13 ed. Philadelphia: PA: Saunders Elsevier; 2011. 1003-11.

15. Cunningham FG, Leveno KJ, Bloom SL, Dashe JS, Hoffman BL, Casey BM, et al. Obstetrical Analgesia and Anesthesia. Williams Obstetrics. 25 ed. Philadelphia: McGraw-Hill Education; 2018. 1066-104.

16. Jain V, Saade GR, Garfield RE. Uterine contraction. Encyclopedia of reproduction. 1999;4:932-42.

17. Gaspar R, Gal A, Galik M, Ducza E, Minorics R, Kolarovszki-Sipiczki Z, et al. Different roles of $\alpha 2$-adrenoceptor subtypes in non-pregnant and late-pregnant uterine contractility in vitro in the rat. Neurochem Int. 2007;51(5):311-8.

18. Holzman C, Senagore P, Tian Y, Bullen B, DeVos E, Leece C, et al. Maternal catecholamine levels in midpregnancy and 
risk of preterm delivery. Am J Epidemiol. 2009;170(8):1014-24.

19. Kim T-S, Bae J-S, Park J-M, Kang S-K. Hemodynamic effects of continuous intravenous injection and bolus plus continuous intravenous injection of oxytocin in cesarean section. Korean $\mathrm{J}$ Anesthesiol. 2011;61(6):482.
20. Hassani V, Movaseghi G, Safaeeyan R, Masghati S, Yekta BG, Rad RFJA, et al. Comparison of ephedrine vs norepinephrine in treating anesthesia-induced hypotension in hypertensive patients: randomized doubleblinded study. 2018;8(4). 